\title{
Analyzing the Corporate Social Responsibility Disclosure: Mixed Method Applied on SME and Large Organizations
}

\author{
Youssef Saida $^{1}$ \\ ${ }^{1}$ ESCA Ecole de Management, Morocco \\ Correspondence: Youssef Saida, ESCA Ecole de Management, Casablanca, 7, Rue Abou Youssef El Kindy, Bd. \\ Mly Youssef 20 070, Casablanca, Morocco. E-mail: y.saida@yahoo.fr
}

\author{
Received: July 15, 2019 Accepted: July 31, $2019 \quad$ Online Published: November 19, 2019 \\ doi:10.5539/ass.v15n12p48 URL: https://doi.org/10.5539/ass.v15n12p48
}

\begin{abstract}
Modern organization has to deal with different stakeholders expectations. Indeed, organization activities and practices should be designed and conducted to be sustainable. So, it is required from organization to be socially responsible and operate with integrity regarding the environment. This organizational behavior is called the corporate social responsibility - CSR. In that case, organization should disclose how it is socially responsible. CSR disclosure is recognized as a tool to enhance corporate reputation. This research aims to deals with the content of the CSR disclosure and in that case the possibility to predict the CSR approach throughout specific CSR-related information. In this paper, we investigate about the nature of CSR disclosure content and to what extent specific CSR-related information - CSR approach could be predicted. The sample of this research contains 58 organizations that had been awarded the label of the CSR in Morocco. A content analysis of websites is used for each organization's CSR communication, found in the corporate websites or annual reports. We use mixed research method for analyzing the content of the CSR disclosure. This method used coding system for analyzing deeply the content related to the CSR and after that the discriminant analysis for testing the ability to predict the CSR approach nature. As results, we raised the CSR disclosure characteristics and hence we explicit how specific CSR-related information highlight different levels of ability to predict CSR approach nature. Our findings, when confronted to the literature, explicit convergences about the nature and the predictability of CSR disclosure content.
\end{abstract}

Keywords: corporate social responsibility, disclosure, corporate strategy, information, stakeholders, isomorphism, content analysis

\section{Introduction}

In modern business landscape, organization should meet by its strategies and functions not only the micro-environment stakeholders' expectations, but also the expectations of the larger society. Recently, several organizations integrate specific sustainable activities. These activities are conducted in long-term in order to meet stakeholders' expectations and gain competitive advantages. CSR-related activities are conducted in nature in long-term.

Given the stimulus of these CSR-related activities, it is argued that circumstances like: financial markets, new pressures, multinationals power and legitimacy, poverty, and the environmental degradation are the requirements of being sustainable and acting with more integrity regarding the society. By integrating these requirements into business strategy, organization meets expectations of different stakeholders (employees, customers, suppliers, $\mathrm{NGO}$, etc.). Otherwise stated, organization seeks the support of these various stakeholders for operating with more confidence and commitment. This organizational behaviour is important to gain competitive advantage throughout balancing between financial performance and social performance. Consequently, organization attempts periodically to display to what extent its strategies and practices are sustainable. These CSR-related activities disclosing emphasizes how organization is socially responsible, and how sustainability requirements are integrated into its practices and functions. CSR disclosure is a part of the corporate disclosure. In this sense, organization looks for being acknowledged as responsible and accountable for its activities and businesses. The CSR disclosure content should provide adequate and sufficient information to reduce the information asymmetry between organization and its stakeholders.

Theoretically, the nature of CSR disclosure content puts the accent on how organization claims legitimacy and 
enhances its reputation by being socially responsible. So, CSR disclosure content characteristics shed the light on the fact that there is an integrated approach in order to meet the sustainability responsibilities (economic, social and environmental). However, the CSR disclosure nature seems to be not deliberately studied. In fact, the previous researches shed the light largely on the CSR disclosure form and the relationship between the financial performance and social performance. The aim of this research is to investigate about the nature of CSR disclosure and then analyse to what extent this disclosure could be discriminated throughout specific criterion.

The theoretical background of this paper is based on the existing literature concerning the main aspects of the research. First, the literature outlining CSR practices recognized as a policy for adopting an organizational sustainable behaviour towards stakeholders. Second, the CSR disclosure literature is also used to give explanation the importance of this tool to provide useful information and content to enhance corporate image and reputation. Third, specific CSR disclosure content characteristics are highlighted to analyse deeply the CSR approach, and hence underlining whether the size or the sector impact the CSR disclosure trend.

\section{Literature Review}

CSR is a set of practices conducted to meet four responsibilities such as: economic, legal, ethical and discretionary (Carroll, 1991; Jamali, 2008). These responsibilities are required from the environment for being socially responsible and operating with integrity throughout strategies and functions. So, CSR could be seen as a voluntary integration, by organizations, of social and environmental issues in their commercial operations and in their relationships with specific stakeholders (Ciliberti, Pontrandolfo, \& Scozzi, 2008). These responsibilities are met from organization for being sustainable (Dao, Langella, \& Carbo, 2011; Hutchins \& Sutherland, 2008; Johnson, 2015; Ortas, Moneva, \& Álvarez, 2014). The literature in CSR reveals that all of the definitions have three points in common. First, the CSR-related activities are conducted to meet the stakeholders' expectations. Second, theses CSR-related activities are conducted voluntarily. Third, all the CSR-related activities are conducted to achieve a set of social, economic and environmental responsibilities (J. Barrena Martínez, López Fernández, \& Romero Fernández, 2016; Basu \& Palazzo, 2008; Reverte, 2009). In this sense, organization displays periodically to what extent its businesses meet these sustainability responsibilities. Accordingly, CSR disclosure should be made by specific form and thus the content should encompass specific characteristics regarding the CSR-related activities and practices.

\subsection{CSR Disclosure}

CSR disclosure is a set of practices related to reporting on CSR activities. It could be defined as a result of corporation awareness regarding social and environmental issues (Reverte, 2009). Effectively, it is reporting about social and environmental issues to take into account the public and stakeholders expectations that have emerged (Kolk \& Pinkse, 2010). Otherwise stated, organization discloses a great deal of information, such as expenditures related to environmental protection and climate change, charity donations, and employee welfare. In this case, it is communicated all CSR-related information which are normally not reported in financial statements (Dhaliwal, Li, Tsang, \& Yang, 2014). Therefore, it is acknowledged as a tool by which organization can efficiently be recognized as responsible and accountable for its activities (Ntim \& Soobaroyen, 2013). In other words, it is a is a proxy for the measurement of CSR activities (Saleh, Zulkifli, \& Muhamad, 2010). In the same perspective, disclosing CSR-related information is how organization dialogues with specific stakeholders in the larger society (Farook, Kabir Hassan, \& Lanis, 2011). This dialogue is conducted to assess the corporation contribution to economic and technological progress (D. Dhaliwal et al., 2014; Reverte, 2009). Furthermore, it could be seen as a mean by which corporate governance ensure the organizational legitimacy (Khan, Muttakin, $\&$ Siddiqui, 2013), and thus strengthen the organization's desired image (Cohen, Holder-Webb, Nath, \& Wood, 2011).

Given the purpose of CSR disclosure, we seek to reduce the information asymmetry between organization and its stakeholders (Cohen et al., 2011; Jizi, Salama, Dixon, \& Stratling, 2013). Indeed, organization disclosures information needed by stakeholders, who require information about organization's social and environmental responsibility and interactions with environment (Holder-Webb, Cohen, Nath, \& Wood, 2009). While disclosing this kind of information, organization behaves as a socially responsible (De Tienne \& Lewis, 2005) by providing incrementally useful information to specific stakeholders like investors to support their decision making process (D. S. Dhaliwal, Radhakrishnan, Tsang, \& Yang, 2012). Through CSR reporting, organization is communicating nonfinancial information that expands sustainability issues beyond environmental considerations (Cohen et al., 2011).

In the context of CSR disclosure, organization ask for being accountable to a wider audience than shareholder and creditor groups (Reverte, 2009). Indeed, it is reported information that may be useful for different 
stakeholders, while it disclosure a wide range of practices and actions related to suppliers, customers, employees, social contributions and public safety, health in the workplace (Cuadrado-Ballesteros, Rodríguez-Ariza, \& García-Sánchez, 2015). Especially, reporting CSR-related information is how organization manage its responsibilities not just towards shareholders, but also to other stakeholders for instance: employees, customers, competitors, suppliers, distributors, the local community in which the organization operates, the general public, and the natural environment. By doing so, organization makes stakeholders satisfaction an important component of its corporate strategy (Dhaliwal et al., 2014; Dias, Rodrigues, \& Craig, 2016). This satisfaction is increasingly required when these stakeholders are powerful and have legitimate and urgent claims on the organization (Banerjee, 2008). These stakeholders are people and groups who can affect or who are affected by organization policies and practices. In that context, organization operates more in stakeholder-oriented environment than in shareholder-oriented environment (Dhaliwal et al., 2012). A good relationship with these stakeholders is a source of competitive advantage, and achieving better economic results (Dias et al., 2016). Besides, leveraging these stakeholders is highly recommended to gain sustained strategic advantages over the competitors (Sen, Bhattacharya, \& Korschun, 2006).

Regarding CSR disclosure form, several researches have treated determinants of CSR disclosures conducted by the organization. These determinants include the size of the organization (Holder-Webb et al., 2009), financial performance (Barnett \& Salomon, 2006; Cheng, Ioannou, \& Serafeim, 2014; Surroca, Tribó, \& Waddock, 2010), age of the organization (Kansal, Joshi, \& Batra, 2014), governance mechanisms (Farook et al., 2011; Giannarakis, 2014; Jamali, 2008; Jizi et al., 2013; Khan et al., 2013) and nature of the industry (Jennings \& Zandbergen, 1995; Muttakin, Khan, \& Azim, 2015; Ntim \& Soobaroyen, 2013; Reverte, 2009; Roberts, 1992). Each determinant of CSR disclosure emphasizes to what extent corporation discloses its CSR-related information throughout specific form (Holder-Webb et al., 2009; Reverte, 2009).

\subsection{CSR Disclosure Characteristics}

While the question of the CSR disclosure content is a matter for several academics researches, it is obvious from the CSR-related practices development in both stakeholder-oriented environment and shareholder-oriented environment that there is a need for more insights about this aspect. This CSR disclosure content encompasses particular characteristics related to CSR-related activities and practices.

\subsubsection{CSR Components}

CSR disclosure content shed light principally on corporate responsibilities regarding the larger society. These responsibilities are the components of the CSR disclosure. It is related to economic, social and environmental issues. Each CSR component emphasizes how organization tackles this threefold impact throughout specific actions to promote relationship with different stakeholders (Cuadrado-Ballesteros et al., 2015). In that respect, organization discloses information about employee relations, environmental dimension, consumerism phenomenon, NGO involvement, governmental relations, business giving, minorities and underprivileged person, stockholder relations and economic activities (Hamid, 2004; Saleh et al., 2010). Regarding the disclosure of specific CSR component, organizations with particular characteristics such as: high public visibility; more important environmental impact; less favorable public images, disclose more social responsibility information. Organizations provide environmental information when their businesses impact potentially the environment. Besides, organizations seeking to make more the visibility among specific stakeholders are more probable to give attention to community involvement issues, and thus disclose information related to such involvement (Branco \& Rodrigues, 2008).

Some researchers investigated about the design of the CSR disclosure content as one of the areas of corporate governance (Hamid, 2004). Indeed, governance mechanisms like the structure is used to reduce legitimacy gap through environmental and social reportings (Khan et al., 2013). For this reason, annual reports and statements contain information related to environmental policy statements; codes of ethics, codes of practice or statements of values; other policy statements (Robertson \& Nicholson, 1996). Integrating corporate governance in CSR disclosure is highly required by investors (Cohen et al., 2011), and seems to be a global phenomenon that cuts across countries and sectors (Kolk \& Pinkse, 2010)

\subsubsection{CSR Activities}

CSR related activities are a set of practices conducted by corporation to achieve its three responsibilities. These activities are related to CSR components. Each component is conducted by specific activities and practices. By disclosing CSR-related activities, organization measures its contributions in all CSR areas (Ntim \& Soobaroyen, 2013) throughout discriminating its ethical behavior in these types of reporting activities (De Tienne \& Lewis, 2005). This ethical behavior gives emphasis to how managers view integrity, and how they have the incentive to 
bring into play CSR activities strategically and opportunistically (Pyo \& Lee, 2013). In particular, promoting this organizational behavior enhances shareholder wealth through increasing profit (Holder-Webb et al., 2009), attains a good relations with their stakeholders (Branco \& Rodrigues, 2008), meets societal norms, demands and expectations (Evangelinos, Skouloudis, Jones, Isaac, \& Sfakianaki, 2016), shapes the perception of stakeholders or manage, (Wang, Song, \& Yao, 2013) and attract special attention from policymakers and academics (Uddin, Siddiqui, \& Islam, 2018). In sum, promoting CSR-related activities have a positive impact on a organization's market value in the long term (D. S. Dhaliwal et al., 2012; Wuttichindanon, 2017) as a result of accomplishing a good customers' risk assessment and reducing the risk of governmental pressures (Wang et al., 2013) in order to gain the public's confidence (Jizi et al., 2013).

\subsubsection{CSR Stakeholders}

Given the CSR-related activities disclosing, it seems to be constantly based on stakeholders' expectations. Indeed, organization reveals how it is accomplishing the integration of CSR processes (social, environmental, ethical and human rights) into core business operations and strategy (Evangelinos et al., 2016). This integration is conducted by prioritizing stakeholders based on their power and legitimacy (Jamali, 2008).

Internally, organization discloses its behavior to the micro-environment. This context contains those domestic interest groups (customers, employees, suppliers, etc.) straightforwardly linked to the organization businesses. This organizational behavior looks for exercising power over their decisions (Jesús Barrena Martínez, López Fernández, \& Romero Fernández, 2016) and expressing its values towards internal stakeholders (Herrera Madueño, Larrán Jorge, Martínez Conesa, \& Martínez-Martínez, 2016).

Externally, organization reports CSR-related information towards macro-environment. This context encompasses communities and the public (Wuttichindanon, 2017). This disclosure should be carefully managed in order to leverage the corporate performance (Herrera Madueño et al., 2016) and improve the organizational legitimacy (Khan et al., 2013; Saleh et al., 2010)

\subsubsection{CSR Management System}

CSR reports is by which corporation discloses how it undertakes both sustainability and social responsibilities towards the environment. To fit the particular stakeholders expectations and pressures, organizations need to implement CSR management systems across the supply chain (Ciliberti, Pontrandolfo, \& Scozzi, 2008). This management system is a facilitator to penetrate new markets and provide value-added solutions to improve competitiveness and enhance reputation (Azapagic, 2003).

While disclosing CSR management system, specific CSR-related information are highlighted. In CSR reports, organization emphasizes how CSR is contextual and dynamic by underlining the geographical location of the CSR-related activities (Asif, Searcy, Zutshi, \& Fisscher, 2013). Besides, it is reported how these activities are conducted through laying emphasis on using supply chain resources to develop sustainability capabilities in order to deliver sustainable value towards different stakeholders and gain competitive advantage (Dao et al., 2011). Otherwise stated, supply chain management should be sustainable. So, CSR reports underline to what extent organization managers consider sustainable supply chain management issues for not only their businesses but also their supply chain partners (Ortas et al., 2014). It is highlighted how the management of supply chain attempts to attain a specific integration of the three dimensions of sustainability (economic, environmental, and social) (Ciliberti et al., 2008).

Sustainability integration implies that the supply chain management has to use appropriate tools which allow measuring corporation' sustainability performance (Ortas et al., 2014). In this sense, CSR disclosure accentuates tools used by business processes to transfer supply chain partners' socially responsible behaviors (Ciliberti et al., 2008). These tools could be the auditing, reporting, verification and ethical behavior based on specific guidance standards like ISO (Castka \& Balzarova, 2008; Maas \& Reniers, 2014; Schwartz \& Tilling, 2009) or specific actions conducted to enhance the corporate reputation (Alsop, 2004).

Theoretically, sustainable supply chain management encompasses a set of processes that use specific tools to enhance corporation social performance. Consequently, disclosing CSR-related information shed light on how organizations could integrate CSR with existing standardized management systems. This integration requires to be organized through the development of an organization-wide infrastructure to integrate CSR into business processes (Asif et al., 2013; De Tienne \& Lewis, 2005). This means that, integration implies a specific level of formalization and institutionalization in the organizational setting (Asif et al., 2013). So, CSR disclosure highlights to what extent organization implements socially responsible actions throughout using standards, (Mežinska et al., 2015) for the effective development of sustainability capabilities (Dao et al., 2011). 


\subsubsection{CSR Determinants}

Even as integration is systematically (Asif et al., 2013; Ciliberti et al., 2008; Mežinska et al., 2015; Ortas et al., 2014), CSR activities are shaped by specific determinants. Theoretically, CSR-related information underlines the corporate social responsibility determinants. Indeed, CSR determinants refer to organization motivations and stimulus to be socially responsible. These determinants, called isomorphism, mean why organization would be socially responsible based on specific approach (Jennings \& Zandbergen, 1995). First, normative isomorphism when organization is integrating social and environmental issues with great confidence due to its professional experience and interaction with the environment. Second, mimetic isomorphism is when organization is socially responsible by imitating practices and strategies of the leaders in the industry. Third, coercive isomorphism is when organization considers political and legal pressure exerted by regulatory power (i.e. government) regarding the sustainability integration (Martínez et al., 2016).

\subsubsection{CSR Approach}

Corporate social responsibility approach refers to how organization integrates the sustainability requirements into corporate strategy. These requirements refer to stakeholders' expectation to balance between financial and social performance (Madueño et al., 2016; Petrini \& Pozzebon, 2009; Surroca et al., 2010). Indeed, disclosing CSR-related approach is about emphasizing the potential to make organizational practices more transparent and socially responsible (Asif et al., 2013). First, the corporate social responsibility could be seen as a source of value creation when organization is socially responsible by conviction due to the previous professional experience. Based on this approach, organization develops an organization-wide infrastructure that will address different stakeholder requirements for improving quality of life in the workplace, local community, and society at large (Asif et al., 2013; Martínez et al., 2016; Ortas et al., 2014). Second, sustainability disclosure could emphasize CSR activities as a management tool when organization assumes this responsibility for mitigating its business negative impact and supporting external relationships (Castka \& Balzarova, 2008; Cruz, 2009; Maas \& Reniers, 2014; Schwartz \& Tilling, 2009). Third, this approach is philanthropic when organization provides skills and funds to conduct short-term benefits activities. So, there is a misalignment between business and sustainable practices. In that context, organization has an incentive to display their CSR-related activities only to fit expectation of specific stakeholders (Pyo \& Lee, 2013; Sen et al., 2006).

Theoretically, CSR approach is the most important CSR-related aspect disclosed by organizations (Asif et al., 2013; Azapagic, 2003; Ciliberti et al., 2008; Dao et al., 2011; Mežinska et al., 2015). By CSR disclosure, organization attempts to display specific CSR-related information in order to highlight CSR approach characteristics (Asif et al., 2013; Leon-Soriano, Muñoz-Torres, \& Chalmeta-Rosaleñ, 2010; Lozano, 2012). In other words, CSR disclosure content nature underline to what extent CSR activities are integrated systematically. The level of CSR integration is highlighted by CSR reports content, displaying all the CSR disclosure characteristics exhibited previously. Besides, there is a lack of theoretical framework about the impact of the organization size and sector on the CSR disclosure content nature (Martínez et al., 2016).

In this paper, we intend to investigate about the nature of the CSR disclosure and afterwards the option to predict the CSR approach, as the main characteristic (Azapagic, 2003; Ciliberti et al., 2008; Dao et al., 2011, 2011; Key \& Popkin, 1998; Mežinska et al., 2015), throughout specific criterion. After analysing the corporate social responsibility disclosure content throughout the coding system, we choose CSR activities; CSR management system tool; CSR management system formalization and CSR determinants as the most characteristics used for approaching CSR disclosure (Asif et al., 2013; Ciliberti et al., 2008; Maas \& Reniers, 2014; Ortas et al., 2014). In addition, we add Size and Sector as indicators to analysis deeply the CRS disclosure characteristics (Martínez et al., 2016). Hence, we investigate how independent variables - CSR disclosure characteristics discriminate among the members of groups constructed based on CSR approach.

Six hypotheses were set up:

$\boldsymbol{H}_{1}$ : "CSR management system tools" is a good predictor of corporate social responsibility approach.

$\boldsymbol{H}_{2}$ : "CSR management system formalization" is a good predictor of corporate social responsibility approach.

$\boldsymbol{H}_{3}$ : "CSR determinants" is a good predictor of corporate social responsibility approach.

$\boldsymbol{H}_{4}$ : "Size" is a good predictor of corporate social responsibility approach.

$\boldsymbol{H}_{5}$ : "Sector" is a good predictor of corporate social responsibility approach.

$\boldsymbol{H}_{6}$ : "CSR activities" is a good predictor of corporate social responsibility approach. 


\section{Method}

For conducting content analysis and testing the hypotheses cited above, mixed research approach is used in this study, because it is well-matched to the subject of our research.

\subsection{Participant (Subject) Characteristics}

In this research, we aim to study the CSR disclosure, and thus investigate about the possibility for predicting corporate social responsibility approach throughout specific aspects. Our research is conducted with companies that had been awarded the label of the corporate social responsibility in Morocco. This choice is justified by the fact that these companies published regularly their corporate social responsibility statements and reports in their websites. As well, these companies are operating in different industries and represent all sizes companies categories. Consequently, we cover for the most part the Moroccan business landscape.

\subsection{Sampling Procedures}

To fit the purpose of this research, convenience sampling method was applied for getting data (financial statements, annual reports, newsletters, etc.) from companies' websites. 58 companies (large and SME) were involved in the study.

\subsection{Measures and Covariates}

For this research, the data-collection process was based on data found in companies' websites. We use a content analysis of websites for each company in order to outline the nature of its corporate social responsibility disclosure. First, a code matrix is constructed (appendix A). Therefore, coding system used each code for coding segments in each organization document. Each code emphasizes a specific characteristic related to each organization's corporate social responsibility disclosure. Second, we use the content analysis results related to whether specific codes such as: CSR_App; CSR_Mgt_Sys/Form; CSR_Det; CSR_Mgt_Sys/T and CSR_Act appear in all documents. In other words, we transform these codes to qualitative variables. As well, we use sector and size as variables in this classification analysis. Hence, we have seven qualitative variables.

In that case, three groups of companies are constructed. Based on the corporate social responsibility disclosure, we use six qualitative variables for these three groups. The reasons of this choice were efficiency in data gathering to fit the requirements of discriminant analysis.

In this survey, we used qualitative variables. First, corporate social responsibility approach is a qualitative variable. It contains three categories such as: value creation; management tool and philanthropy. It was measured throughout companies' corporate social responsibility disclosure content analysis driven by which one of three subcodes (CSR_App/Corp_Ph; CSR_App/Mgt_T and CSR_App/VC) appear in companies documents. While doing so, we try to highlight the nature of the corporate social responsibility approach. Second, six qualitative variables such as: Size; Sector; CSR activities; CSR management system tool; CSR management system formalization and CSR determinants representing corporate social responsibility characteristics. Indeed, CSR activities and CSR management system formalization are Boolean variables (yes or no). CSR management system tool and CSR determinants are categorical variables. These two variables were measured throughout categories representing subcodes related respectively to codes such as: CSR_Mgt_Sys/T and CSR_Det. In addition, size and sector are categorical variables, each of which contains two categories respectively: Industry/Service and SME/Large.

\section{Results and Data Analysis}

This section illustrates the results of content analysis conducted using MAXQDA and discriminant analysis conducted throughout SPSS. The data used in this analysis are from CGEM data file. MAXQDA and SPSS outputs are displayed in tables.

Based on coding system, we seek to display whether each code appear in all documents and how frequently it came compared to other codes. Besides, we are interested to emphasize to what extent codes are overlapping each other. All codes results are highlighted per document group, and thus discriminated by variable such as: organization size.

Table 1 recaps whether each code (or subcode) appears in each organization document. For example, we can see that codes like: CSR_App and CSR_Det appear in all organization documents. As well, others codes and theirs subcodes such as: CSR_Mgt_Sys; CSR_Stak and CSR_Comp appear in the most organization documents. However, specific codes like CSR_Act or subcodes such as: CSR_Det/Coe_Iso; CSR_Mgt_Sys/T_Verif; CSR_Mgt_Sys/T_Ethic and CSR_Mgt_Sys/T_CA don't appear in the most organization documents.

The second table highlights how frequently each code (or subcode) appears in the documents. Indeed, the size of 
the nodes is calculated based on total number of codes. In other words, the size refers to the number of segments coded in each document. For example, codes like CSR_Act and CSR_Comp came more often than the other codes in all documents.

In the Table 3, we emphasize which codes came the most often in each organization document. In that case, we have codes like CSR_Stak; CSR_Act and CSR_Comp. However, in the Table 4 we summarize which codes came the most often in all documents. So, we have codes such as: CSR_Mgt_Sys/G; CSR_Stak; CSR_Act and CSR_Comp.

Table 1. Codes matrix per organization document

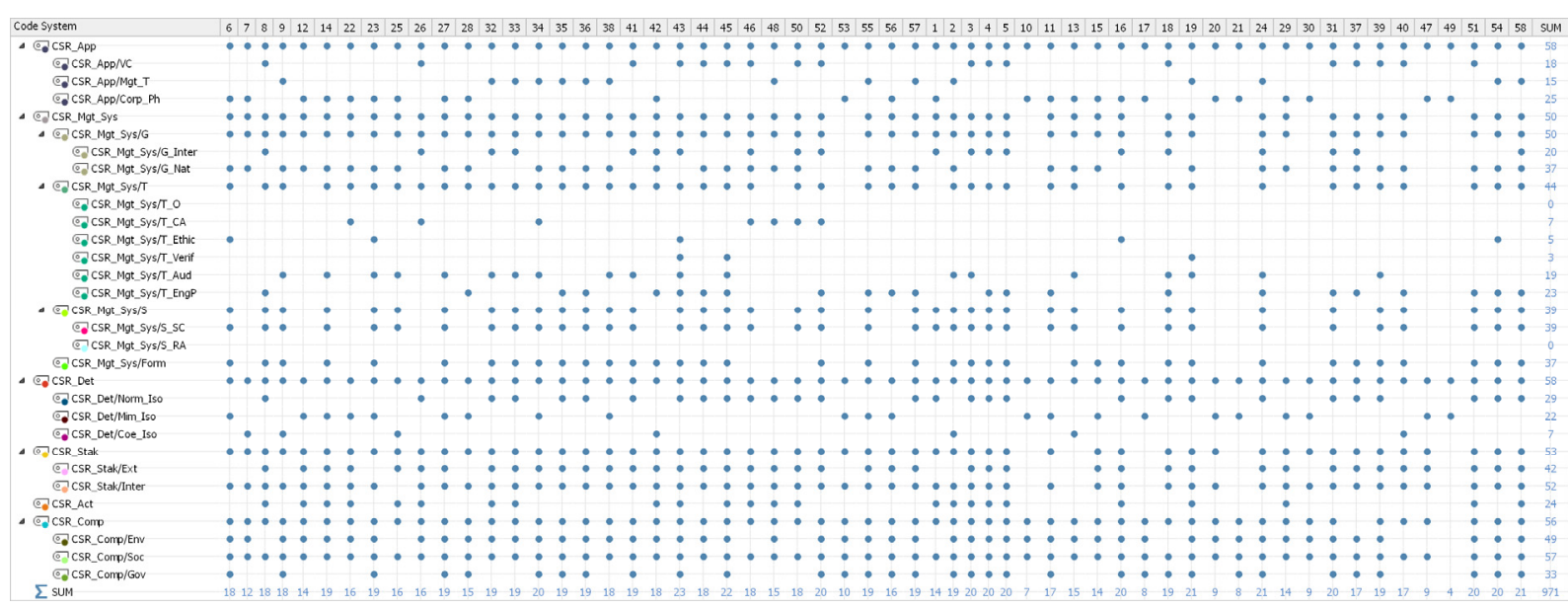

Table 2. Codes frequencies matrix across all documents

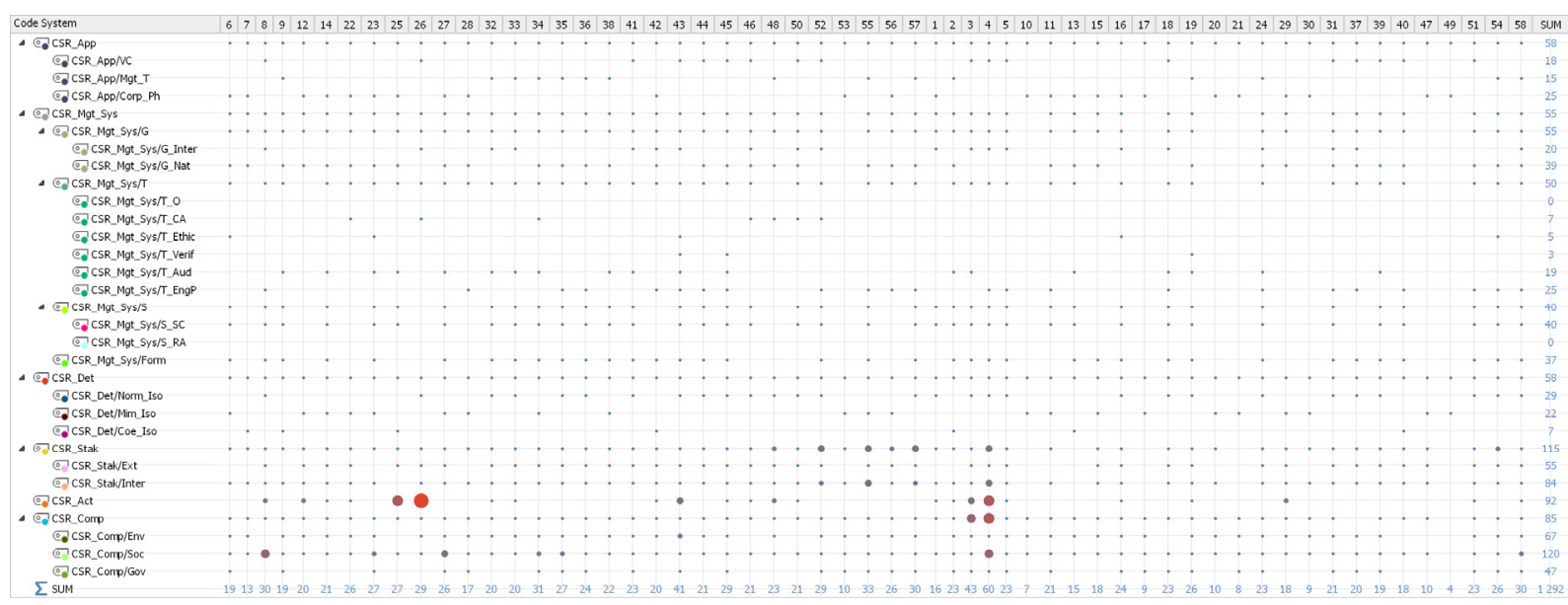

Table 3. Codes frequencies matrix per organization document

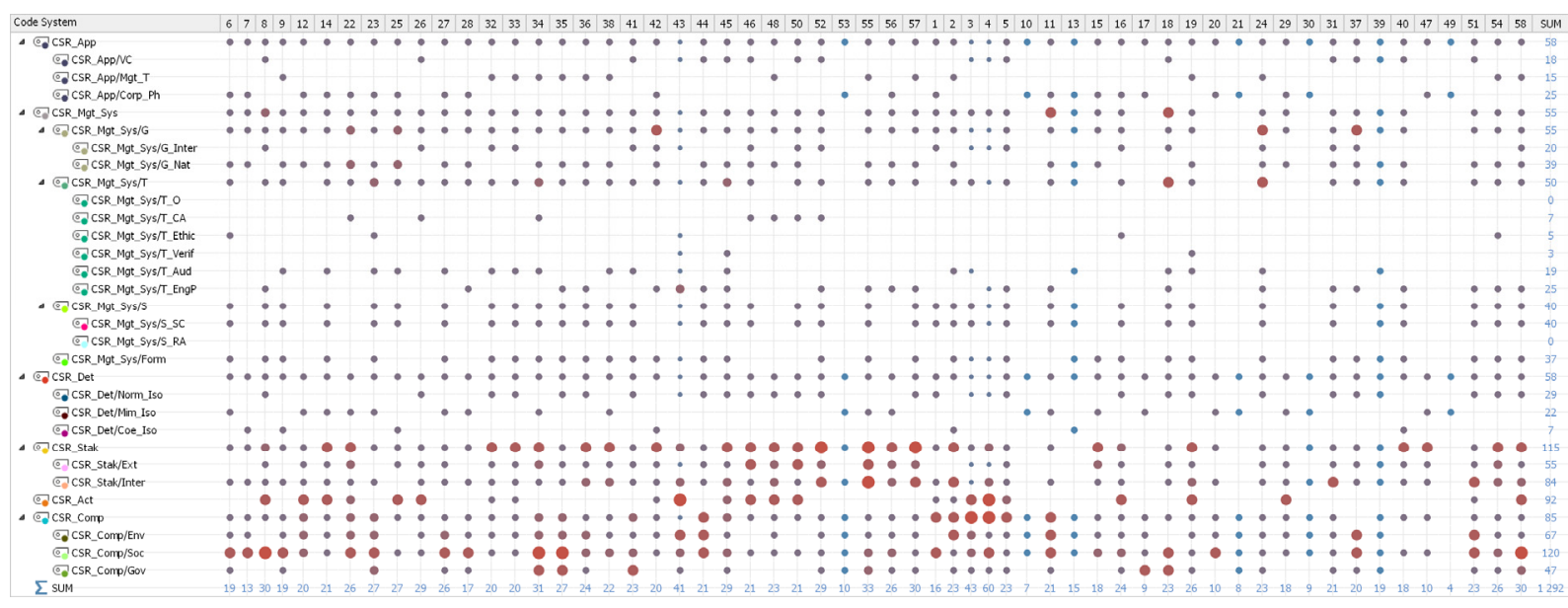


Table 4. Code frequencies matrix across documents

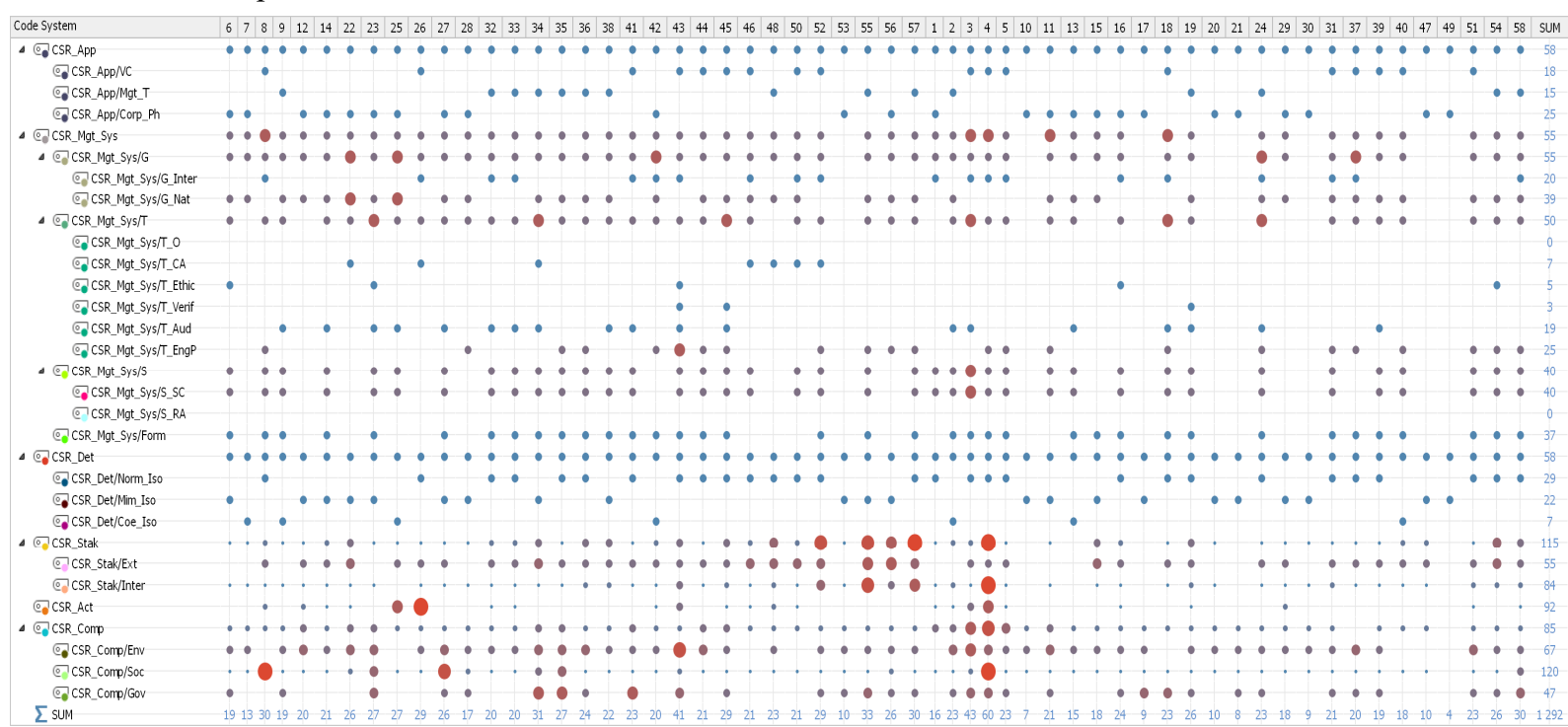

In Tables 5 and 6, we recapitulate results showed above per sector. In fact, the most of codes appear in industry group. In addition, codes like: CSR_Stak; CSR_Act and CSR_Comp came the most frequently than the other codes in the two groups (industry and service). These codes came more often in each group. On the other side, each code and his subcodes came more often in industry group than the service group except the code CSR_Comp and the subcode CSR_App/Corp_Ph (appendix B).

Table 7 displays how often codes overlap each other in all documents. In fact, we can observe that the code CSR_App overlaps more often with CSR_Det. Subcodes like: CSR_App/Corp_Ph; CSR_App/Mgt_T and CSR_App/VC overlapping respectively more often with CSR_Det/Mim_Iso and CSR_Det/Norm_Iso. In addition, CSR_Mgt_Sys overlaps more often with CSR_App than CSR_Det (appendix C).

In Tables 8 and 9, we visualize how often each code is used in each document group (industry \& service) that has certain variable values. In this case, we use as a variable the organization size (SME \& Large organization). In industry group, we can see that the most codes came more often in large organization documents than the SME documents. In service group, we have the same case except for four subcodes such as: CSR_App/Mgt_T; CSR_Mgt_Sys/S and CSR_Det/Coe_Iso.

Table 5. Codes frequencies matrix per sector - nodes presentation

\begin{tabular}{|c|c|c|c|}
\hline Code System & Industry & Service & SUM \\
\hline$\Delta \bigodot_{\bullet}$ CSR_App & 0 & - & 58 \\
\hline$\bigoplus_{C}$ CSR_App/NC & - & - & 18 \\
\hline$\mho_{C}$ CSR_App/Mgt_T & - & - & 15 \\
\hline @CSR_App/Corp_Ph & - & - & 25 \\
\hline$\Delta$ ๑) CSR_Mgt_Sys & - & - & 50 \\
\hline$\Delta \sigma_{0}$ CSR_Mgt_Sys/G & e & - & 50 \\
\hline C)CSR_Mgt_Sys/G_Inter & - & - & 20 \\
\hline C_CSR_Mgt_Sys/G_Nat & - & - & 37 \\
\hline$\Delta \sigma_{0}$ CSR_Mgt_Sys/T & ○ & - & 44 \\
\hline$e_{\text {CSR_Mgt_Sys/T_O }}$ & & & 0 \\
\hline ๑_CSR_Mgt_Sys/T_CA & - & & 7 \\
\hline$e_{\theta}$ CSR_Mgt_Sys/T_Ethic & 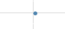 & - & 5 \\
\hline$e_{\text {CCSR_Mgt_SYs/T_Verif }}$ & . & . & 3 \\
\hline CCSR_Mgt_Sys/T_Aud & - & - & 19 \\
\hline$C_{C}$ CSR_Mgt_Sys/T_EngP & - & - & 23 \\
\hline$\Delta$ • & - & - & 39 \\
\hline ๑CSR_Mgt_Sys/S_SC & - & - & 39 \\
\hline C) CSR_Mgt_Sys/S_RA & & & 0 \\
\hline$e_{\theta}$ CSR_Mgt_Sys/Form & - & - & 37 \\
\hline$\Delta \sigma_{C}$ CSR_Det & 0 & - & 58 \\
\hline @CSR_Det/Norm_Iso & - & - & 29 \\
\hline ๑ CSR_Det/Mim_Iso & - & - & 22 \\
\hline ๑CSR_Det/Coe_Iso & & . & 7 \\
\hline$\Delta \varrho_{C}$ CSR_Stak & ○ & - & 53 \\
\hline C) CSR_Stak/Ext & - & - & 42 \\
\hline ๑) CSR_Stak/Inter & - & - & 52 \\
\hline$\varrho_{-C S R \_A c t}$ & - & - & 24 \\
\hline$\Delta \sigma_{\theta}$ CSR_Comp & ○ & - & 56 \\
\hline ๑CSR_Comp/Env & ? & - & 49 \\
\hline CSR_Comp/soc & 0 & - & 57 \\
\hline (_) CSR_Comp/Gov & - & - & 33 \\
\hline$\sum$ sum & 549 & 422 & 971 \\
\hline
\end{tabular}


Table 6. Codes frequencies matrix per sector

\begin{tabular}{|c|c|c|c|}
\hline Code System & Industry & Service & SUM \\
\hline$\Delta \bigodot_{C}$ CSR_APp & 31 & 27 & 58 \\
\hline$\sigma_{\odot}$ CSR_App/NC & 9 & 9 & 18 \\
\hline ๑CSR_App/Mgt_T & 10 & 5 & 15 \\
\hline CSSR_App/Corp_Ph & 12 & 13 & 25 \\
\hline$\Delta \sigma_{g}$ CSR_Mgt_Sys & 30 & 20 & 50 \\
\hline$\Delta$ G]CSR_Mgt_Sys/G & 30 & 20 & 50 \\
\hline$e_{\theta}$ CSR_Mgt_Sys/G_Inter & 10 & 10 & 20 \\
\hline ש_CSR_Mgt_Sys/G_Nat & 23 & 14 & 37 \\
\hline$\Delta$ CSR_Mgt_Sys/T & 27 & 17 & 44 \\
\hline$\sigma_{\theta}$ CSR_Mgt_Sys/T_O & & & 0 \\
\hline @CSR_Mgt_Sys/T_CA & 7 & & 7 \\
\hline שCSR_Mgt_Sys/TEEthic & 3 & 2 & 5 \\
\hline e_CSR_Mgt_Sys/T_Verif & 2 & 1 & 3 \\
\hline @CSR_Mgt_Sys/T_Aud & 12 & 7 & 19 \\
\hline ๑CSR_Mgt_Sys/T_EngP & 12 & 11 & 23 \\
\hline$\Delta$ GCSR_Mgt_Sys/S & 22 & 17 & 39 \\
\hline •CSR_Mgt_Sys/S_SC & 22 & 17 & 39 \\
\hline C] CSR_Mgt_Sys/S_RA & & & 0 \\
\hline$e_{e}$ CSR_Mgt_Sys/Form & 20 & 17 & 37 \\
\hline$\Delta$ ๑CSR_Det & 31 & 27 & 58 \\
\hline ๑CSR_Det/Norm_Iso & 15 & 14 & 29 \\
\hline ๑CSR_Det/Mim_Iso & 12 & 10 & 22 \\
\hline ๑CSR_Det/Coe_Iso & 4 & 3 & 7 \\
\hline$\triangle \sigma_{\partial}$ CSR_Stak & 31 & 22 & 53 \\
\hline (C) CSR_Stak/Ext & 25 & 17 & 42 \\
\hline ఠ]CSR_Stak/Inter & 30 & 22 & 52 \\
\hline$\circlearrowright$ CSR_Act & 14 & 10 & 24 \\
\hline$\Delta \sigma_{\partial}$ CSR_Comp & 31 & 25 & 56 \\
\hline 『CSR_Comp/Env & 27 & 22 & 49 \\
\hline CSR_Comp/Soc & 31 & 26 & 57 \\
\hline$\sigma_{\partial}$ CSR_Comp/Gov & 16 & 17 & 33 \\
\hline$\sum$ SUM & 549 & 422 & 971 \\
\hline
\end{tabular}

Table 7. Codes overlapping frequencies matrix

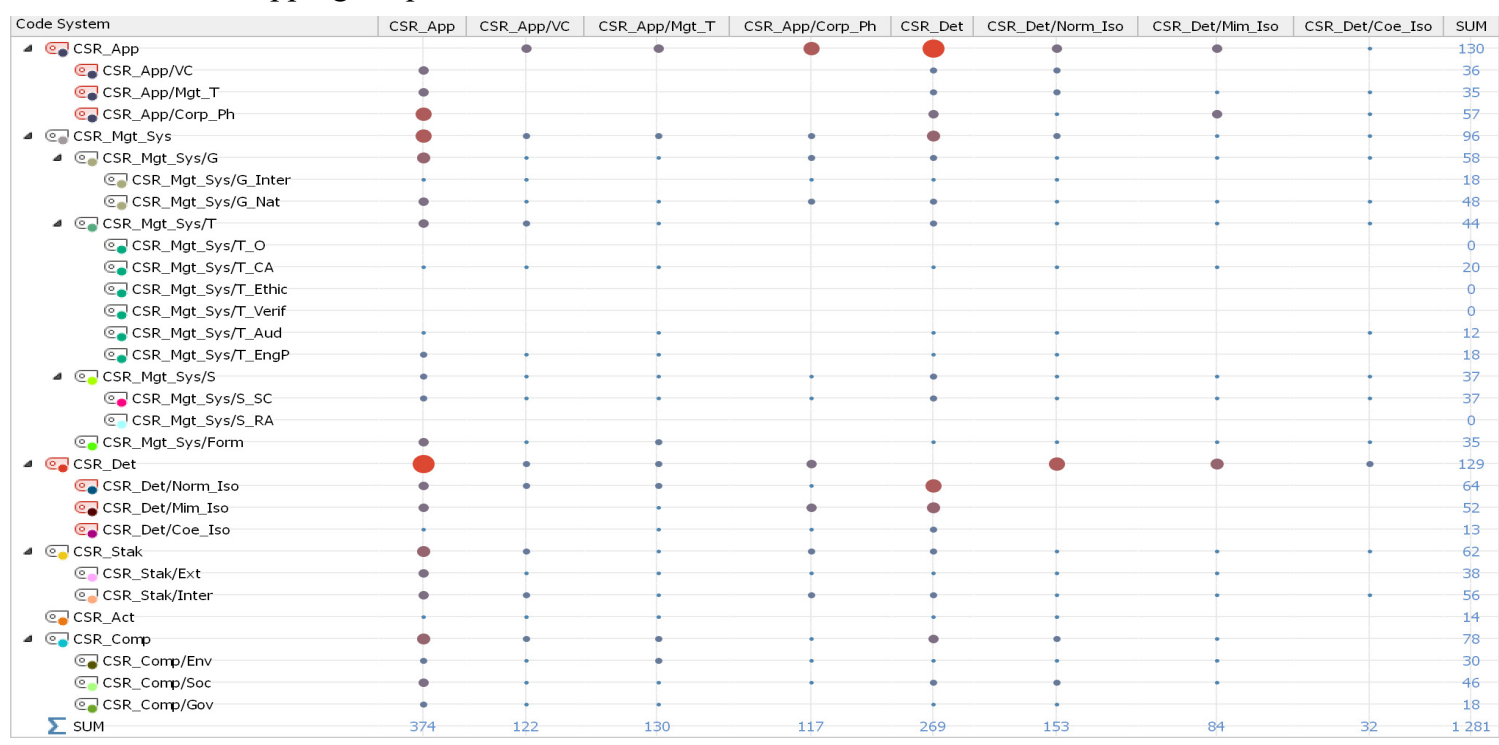

Table 8. Codes frequencies matrix per organization size - Industrial sector

\begin{tabular}{|c|c|c|c|}
\hline & Size $=$ Large & Size $=$ SME & Total \\
\hline$\triangle G_{\bullet}$ CSR_App & $74,2 \%$ & $25,8 \%$ & $100,0 \%$ \\
\hline$\emptyset_{\bullet}$ CSR_App $/ N C$ & $88,9 \%$ & $11,1 \%$ & $100,0 \%$ \\
\hline$\sigma_{\bullet}$ CSR_App/Mgt_T & $60,0 \%$ & $40,0 \%$ & $100,0 \%$ \\
\hline ๑CSR_App/Corp_Ph & $75,0 \%$ & $25,0 \%$ & $100,0 \%$ \\
\hline$\Delta \theta_{\theta}$ CSR_Mgt_Sys & $73,3 \%$ & $26,7 \%$ & $100,0 \%$ \\
\hline D $\varrho_{0}$ CSR_Mgt_Sys/G & $73,3 \%$ & $26,7 \%$ & $100,0 \%$ \\
\hline$D \varrho_{\theta}$ CSR_Mgt_Sys $/ T$ & $78,6 \%$ & $21,4 \%$ & $100,0 \%$ \\
\hline D $\sigma_{0}$ CSR_Mgt_Sys/S & $72,7 \%$ & $27,3 \%$ & $100,0 \%$ \\
\hline$\varrho_{Q}$ CSR_Mgt_Sys/Form & $70,0 \%$ & $30,0 \%$ & $100,0 \%$ \\
\hline$\Delta Q_{0}$ CSR_Det & $74,2 \%$ & $25,8 \%$ & $100,0 \%$ \\
\hline @CSR_Det/Norm_Iso & $73,3 \%$ & $26,7 \%$ & $100,0 \%$ \\
\hline$\sigma_{\bullet}$ CSR_Det/Min_Iso & $83,3 \%$ & $16,7 \%$ & $100,0 \%$ \\
\hline$\Theta_{\text {(CSR_Det/Coe_Iso }}$ & $50,0 \%$ & $50,0 \%$ & $100,0 \%$ \\
\hline$\Delta \sigma_{1}$ CSR_Stak & $74,2 \%$ & $25,8 \%$ & $100,0 \%$ \\
\hline (ㄱ) CSR_Stakkext & $76,0 \%$ & $24,0 \%$ & $100,0 \%$ \\
\hline$\sigma_{8}$ CSR_Stak/Inter & $73,3 \%$ & $26,7 \%$ & $100,0 \%$ \\
\hline$\sigma_{\theta}$ CSR_Act & $92,9 \%$ & $7,1 \%$ & $100,0 \%$ \\
\hline$\Delta \sigma_{\theta}$ CSR_Comp & $74,2 \%$ & $25,8 \%$ & $100,0 \%$ \\
\hline$\sigma_{\bullet}$ CSR_Comp/Env & $70,4 \%$ & $29,6 \%$ & $100,0 \%$ \\
\hline (o) CSR_Comp/Soc & $74,2 \%$ & $25,8 \%$ & $100,0 \%$ \\
\hline$\varrho_{\theta}$ CSR_Comp/Gov & $62,5 \%$ & $37,5 \%$ & $100,0 \%$ \\
\hline$\sum$ SUM & $74,1 \%$ & $25,9 \%$ & $100,0 \%$ \\
\hline$\# \mathrm{~N}$ (Documents) & $23(74 \%)$ & $8(25 \%)$ & $31(100 \%)$ \\
\hline
\end{tabular}


Table 9. Codes frequencies matrix per organization size - Service sector

\begin{tabular}{|c|c|c|c|}
\hline & Size $=$ Large & Size $=$ SME & Total \\
\hline$\triangle \sigma_{C}$ CSR_App & $55,6 \%$ & $44,4 \%$ & $100,0 \%$ \\
\hline$G_{0}$ CSR_App/NC & $55,6 \%$ & $44,4 \%$ & $100,0 \%$ \\
\hline ๑CSR_App/Mgt_T & $40,0 \%$ & $60,0 \%$ & $100,0 \%$ \\
\hline G_CSR_App/Corp_Ph & $61,5 \%$ & $38,5 \%$ & $100,0 \%$ \\
\hline$\Delta \sigma_{0}$ CSR_Mgt_Sys & $55,0 \%$ & $45,0 \%$ & $100,0 \%$ \\
\hline D $\sigma_{0}$ CSR_Mgt_Sys/G & $55,0 \%$ & $45,0 \%$ & $100,0 \%$ \\
\hline D $G_{0}$ CSR_Mgt_Sys $/ T$ & $52,9 \%$ & $47,1 \%$ & $100,0 \%$ \\
\hline$\triangleright \sigma_{0}$ CSR_Mgt_Sys/S & $47,1 \%$ & $52,9 \%$ & $100,0 \%$ \\
\hline (6) CSR_Mgt_Sys/Form & $58,8 \%$ & $41,2 \%$ & $100,0 \%$ \\
\hline$\Delta \sigma_{\Delta}$ CSR_Det & $55,6 \%$ & $44,4 \%$ & $100,0 \%$ \\
\hline G_CSR_Det/Norm_Iso & $57,1 \%$ & $42,9 \%$ & $100,0 \%$ \\
\hline @CSR_Det/Mim_Iso & $60,0 \%$ & $40,0 \%$ & $100,0 \%$ \\
\hline @CCSR_Det/Coe_Iso & $33,3 \%$ & $66,7 \%$ & $100,0 \%$ \\
\hline$\Delta$ ( & $54,5 \%$ & $45,5 \%$ & $100,0 \%$ \\
\hline (ㄱ) CSR_Stak/Ext & $58,8 \%$ & $41,2 \%$ & $100,0 \%$ \\
\hline (]) CSR_Stak/Inter & $54,5 \%$ & $45,5 \%$ & $100,0 \%$ \\
\hline COCSRAct & $60,0 \%$ & $40,0 \%$ & $100,0 \%$ \\
\hline$\Delta$ CSR_Conp & $56,0 \%$ & $44,0 \%$ & $100,0 \%$ \\
\hline$\varrho_{0}$ CSR_Comp/Env & $68,2 \%$ & $31,8 \%$ & $100,0 \%$ \\
\hline (a) CSR_Comp/Soc & $57,7 \%$ & $42,3 \%$ & $100,0 \%$ \\
\hline C. CSR_Comp/Gov & $52,9 \%$ & $47,1 \%$ & $100,0 \%$ \\
\hline & & & \\
\hline \# N (Documents) & $\begin{array}{l}36,1 \% \\
15(55 \%)\end{array}$ & $12(44 \%)$ & $27(100 \%)$ \\
\hline
\end{tabular}

About discriminant analysis, we attempt to investigate about the relationship between one categorical variable and six qualitative variables. In particular, the aim is to know the dimensions needed to express this relationship. Hence, we are interested to predict a categorization based on the qualitative variables in order to measure to what extend the qualitative variables differentiate the categories constructed. In addition, we are interested to examine the degree to which the qualitative variables can be used to discriminate among the groups.

Table 10 recapitulates the analysis dataset in terms of valid and excluded observations. In our study, all of the observations in the dataset are valid.

Table 10. Analysis Case Processing Summary

\begin{tabular}{llcc}
\hline Unweighted Cases & $\mathrm{N}$ & Percent \\
\hline Valid & & 58 & 100,0 \\
& Missing or out-of-range group codes &, 0 & 0 \\
\multirow{4}{*}{ Excluded } & At least one missing discriminating variable &, 0 & 0 \\
& Both missing or out-of-range group codes and at least one missing discriminating variable & 0 &, 0 \\
& Total & 0 &, 0 \\
Total & & 58 & 100,0 \\
\hline
\end{tabular}

The Table 11 displays the distribution of observations into three groups within corporate social responsibility approach. Thus, we can see the frequency of observations into each of the three groups. In this case, we can observe that the corporate social responsibility management system tools mean values are the most important in value creation and management tool groups. However, we haven't the same situation regarding the philanthropy group, corporate social responsibility determinants mean value is the most important. Regarding corporate social responsibility activities, the mean value is the less among the three groups. Additionally, we observe that the weighted number of observations in each group is equal to the unweighted number of observations in each group.

Table 11. Group Statistics

\begin{tabular}{lccccc}
\hline \multirow{2}{*}{ CSR Approach } & \multirow{2}{*}{ Mean } & \multirow{2}{*}{ Std. Deviation } & \multicolumn{2}{c}{ Valid N (listwise) } \\
\cline { 5 - 6 } & & & Unweighted & Weighted \\
\hline & CSR Management System Tools & 2,3333 & 1,60880 & 18 & 18,000 \\
CSR Management System Formalization &, 8333 &, 38348 & 18 & 18,000 \\
Value creation & CSR Determinants & 1,1111 &, 47140 & 18 & 18,000 \\
& Sector & 1,5000 &, 51450 & 18 & 18,000 \\
& Size & 1,7222 &, 46089 & 18 & 18,000 \\
& CSR Activities &, 5556 &, 51131 & 18 & 18,000 \\
\hline
\end{tabular}




\begin{tabular}{|c|c|c|c|c|c|}
\hline \multirow{6}{*}{ Management tool } & CSR Management System Tools & 2,0000 & 1,30931 & 15 & 15,000 \\
\hline & CSR Management System Formalization & ,9333 & 25820 & 15 & 15,000 \\
\hline & CSR Determinants & 1,4667 & ,74322 & 15 & 15,000 \\
\hline & Sector & 1,3333 & ,48795 & 15 & 15,000 \\
\hline & Size & 1,5333 &, 51640 & 15 & 15,000 \\
\hline & CSR Activities &, 4000 & ,50709 & 15 & 15,000 \\
\hline \multirow{6}{*}{ Philanthropy } & CSR Management System Tools & 1,1600 & 1,57268 & 25 & 25,000 \\
\hline & CSR Management System Formalization &, 3200 & ,47610 & 25 & 25,000 \\
\hline & CSR Determinants & 2,0800 & ,49329 & 25 & 25,000 \\
\hline & Sector & 1,5200 & ,50990 & 25 & 25,000 \\
\hline & Size & 1,6800 & ,47610 & 25 & 25,000 \\
\hline & CSR Activities & ,3200 & ,47610 & 25 & 25,000 \\
\hline \multirow{6}{*}{ Total } & CSR Management System Tools & 1,7414 & 1,58458 & 58 & 58,000 \\
\hline & CSR Management System Formalization & ,6379 & , 48480 & 58 & 58,000 \\
\hline & CSR Determinants & 1,6207 & 69655 & 58 & 58,000 \\
\hline & Sector & 1,4655 & ,50317 & 58 & 58,000 \\
\hline & Size & 1,6552 & ,47946 & 58 & 58,000 \\
\hline & CSR Activities & ,4138 & 49681 & 58 & 58,000 \\
\hline
\end{tabular}

In the Table 12, the first column indicates the canonical linear discriminant function. In this analysis, corporate social responsibility approach has three levels and six discriminating variables were used, so two functions are calculated. These functions are a projection of the data onto a dimension that best differentiates between the groups. In the second column, we have the eigenvalue of the matrix product of the inverse of the within-group sums-of-squares and cross-product matrix and the between-groups sums-of-squares and cross-product matrix. In our analysis, the eigenvalue is $\mathbf{1 . 3 7 3}$ for the first function and $\mathbf{0 . 1 0 5}$ for the second one. The importance of each eigenvalue stresses the function's discriminating abilities. As well, the \% of variance indicates that the two functions calculated accounts for $100 \%$ of the discriminating ability of the discriminating variables. The final column is about the canonical correlation of the predictor variables (CSR management system tools, CSR management system formalization, CSR determinants, Size, Sector and CSR activities) and the three groups in corporate social responsibility approach (value creation, management tool and philanthropy). From this analysis, the canonical correlation value is $\mathbf{0 . 7 6 1}$ for the first function and $\mathbf{0 . 3 0 8}$ for the second one.

Table 12. Eigenvalue

\begin{tabular}{ccccc}
\hline Function & Eigenvalue & \% of Variance & Cumulative \% & Canonical Correlation \\
\hline 1 & 1,373 & 92,9 & 92,9 &, 761 \\
2 &, 105 & 7,1 & 100,0 &, 308 \\
\hline
\end{tabular}

The Wilks' Lambda value displayed by the Table 13 is $\mathbf{0 . 3 8 1}$ for the first function and $\mathbf{0 . 9 0 5}$ for the second one. Besides, the Chi-square (50.608) testing that the canonical correlation of the first function calculated is equal to zero. As a result, we have the null hypothesis is that the function has no discriminating ability. This hypothesis is tested using this Chi-square statistic. The $p$-value associated with the Chi-square value is $\mathbf{0 . 0 0 0}$ (smaller than 0.05). So, the null hypothesis is rejected. It indicates that there is a significant difference between the three groups based on the predictor variables. However, the $p$-value associated with the second function Chi-square value (5.243) is $\mathbf{0 . 3 8 7}$ (higher than $\mathbf{0 . 0 5}$ ). So, the null hypothesis is accepted. It indicates that there isn't a significant difference between the three groups based on the predictor variables.

Table 13. Wilks' Lambda

\begin{tabular}{ccccc}
\hline Test of Function(s) & Wilks' Lambda & Chi-square & df & Sig. \\
\hline 1 through 2 &, 381 & 50,608 & 12 &, 000 \\
2 &, 905 & 5,243 & 5 &, 387 \\
\hline
\end{tabular}

The Table 14 shows the coefficients that can be used to estimate the discriminant score.

The magnitudes of these coefficients indicate how strongly the discriminating variables affect the score. In our analysis, we observe that three coefficients such as: "CSR determinants" (0.709), "CSR management system formalization" (0.701) and "CSR management system tools" (0.336) in the first function is greater in magnitude 
than the coefficients for the other three variables (Size, Sector and CSR activities smaller than 0.30). In consequence, CSR determinants, CSR management system formalization and CSR management system tools will have the greatest impact $\left(\boldsymbol{H}_{1}, \boldsymbol{H}_{2}\right.$ and $\boldsymbol{H}_{3}$ are accepted $)$ of the three $\left(\boldsymbol{H}_{4}, \boldsymbol{H}_{5}\right.$ and $\boldsymbol{H}_{6}$ are rejected $)$ on the discriminant score (appendix D).

Table 14. Standardized Canonical Discriminant Function Coefficients

\begin{tabular}{ccc}
\hline & \multicolumn{2}{c}{ Function } \\
\cline { 2 - 3 } & \multicolumn{1}{c}{$\mathbf{1}$} \\
\hline CSR Management System Tools &, 336 &, 222 \\
CSR Management System Formalization &, 701 &,- 461 \\
CSR Determinants &,- 709 &,- 401 \\
Sector &,- 082 &, 623 \\
Size &,- 288 &, 483 \\
CSR Activities &, 107 &, 083 \\
\hline
\end{tabular}

The Table 15 indicates the canonical structure of the discriminant function. It represents the correlations between the six qualitative discriminating variables (CSR management system tools, CSR management system formalization, CSR determinants, Size, Sector and CSR activities) and the dimensions created with the discriminant function. In the analysis, this correlation is strong in the case of CSR determinants (0.638).

Table 15. Structure Matrix

\begin{tabular}{crc}
\hline & \multicolumn{2}{c}{ Function } \\
\cline { 2 - 3 } CSR Determinants & $\mathbf{1}$ & $\mathbf{2}$ \\
\hline CSR Management System Formalization &,- 638 &,- 572 \\
CSR Management System Tools &, 595 &,- 469 \\
Size &, 296 &, 176 \\
Sector &,- 029 &, 476 \\
CSR Activities &,- 073 &, 415 \\
\hline
\end{tabular}

In the Table 16, we find the means of the discriminant function scores by group for the function calculated above. Therefore, we can see that the "value creation" group has a mean of 1.100, the "management tool" group has a mean of $\mathbf{0 . 8 5 8}$ and "philanthropy" group has a mean of $\mathbf{- 1 . 3 0 7}$.

Table 16. Functions at Group Centroids

\begin{tabular}{cccc}
\hline CSR Approach & \multicolumn{2}{c}{ Function } \\
\cline { 2 - 3 } & Value creation & 1,100 &, 359 \\
Management tool &, 858 &,- 479 \\
Philanthropy & $-1,307$ &, 029 \\
\hline
\end{tabular}

Table 17 is similar to the Analysis Case Processing Summary displayed by Table 1 . However, in this table we find "Processed" cases that were successfully classified based on the discriminant analysis. Also, we are listed the reasons why an observation may not have been processed. In the analysis, we can see that all of the observations in the dataset were successfully classified.

Table 17. Classification Processing Summary

\begin{tabular}{llc}
\hline & Processed & 58 \\
\hline \multirow{2}{*}{ Excluded } & Missing or out-of-range group codes & 0 \\
& At least one missing discriminating variable & 0 \\
& Used in Output & 58 \\
\hline
\end{tabular}

The Table 18 shows the distribution of observations into the corporate social responsibility approach groups used as a starting point in the analysis. The default prior distribution is an equal allocation into the three groups. The discriminant function has classified $\mathbf{1 8}$ as value creation, $\mathbf{1 5}$ as management tool and $\mathbf{2 5}$ as philanthropy. So, this function calculated is able to classify all of the observations (appendix E). 
Table 18. Prior Probabilities for Groups

\begin{tabular}{cccc}
\hline \multirow{2}{*}{ CSR Approach } & \multirow{2}{*}{ Prior } & \multicolumn{2}{c}{ Cases Used in Analysis } \\
\cline { 3 - 4 } & & Unweighted & Weighted \\
\hline Value creation &, 333 & 18 & 18,000 \\
Management tool &, 333 & 15 & 15,000 \\
Philanthropy &, 333 & 25 & 25,000 \\
Total & 1,000 & 58 & 58,000 \\
\hline
\end{tabular}

\section{Discussion}

The aim of this paper is to emphasize, throughout content and discriminant analysis, the nature of the CSR disclosure and the option for discriminating among the three groups constructed based on CSR approach. In such a case, six CSR disclosure content characteristics are applied as predictor variables. Our findings involve the explanation of some insights raised by observing the results derived from this mixed analysis. First, CSR disclosure content is more oriented towards emphasizing information related to CSR approach; CSR determinants; CSR stakeholders; CSR components and CSR management system. Nonetheless, CSR disclosure displays widely and analyses deeply information related to CSR stakeholders; CSR components and CSR management system. Information related to CSR approach and CSR determinants are usually disclosed and mutually analysed. This analysis seems to be not sufficient to provide useful insights like the other information mentioned above. Besides, the CSR reports disclose information related to CSR activities when organization conducts specific actions to meet one of the sustainability responsibilities. Regarding the sector, the trend is essentially the same about the information related to CSR stakeholders; CSR components and CSR activities. However, information related to CSR components are analysed deeply in industrial organizations CSR reports. In industrial sector, CSR related information are highly disclosed and deeply analyzed in large organizations than the SME. Second, CSR determinants, CSR management system formalization and CSR management system tools are underlined as indicators that have the strong discriminating ability between the three groups constructed. Consequently, the CSR approach is predominantly determined by the information related to CSR determinants, CSR management system formalization and CSR management system tools. Otherwise stated, these indicators could be used for predicting the CSR approach whether is value creation, management tool or philanthropy. Therefore, how the information related to CSR determinants, CSR management system formalization and CSR management system tools are disclosed and analysed put the accent on the CSR approach nature - value creation, management tool or philanthropy. Besides, the indicators such as: Size, Sector and CSR activities are highlighted as indicators without significant discriminating ability among the three groups constructed. For that reason, these indicators could not be used for predicting the CSR approach nature. Afterwards, the CSR approach nature could be determined not considering the values of these three indicators. These six indicators correspond to the CSR disclosure content related primarily towards the approach used to conduct the sustainable activities. Three indicators - CSR determinants, CSR management system formalization and CSR management system tools are preferred by stakeholders (investors, customers, suppliers, NGO, etc.) because it underlines the CSR approach nature more positively than others indicators - Size, Sector and CSR activities. As well, these indicators allow for a significant comparison between organizations disclosing theirs approaches for managing CSR related activities. The indicators like Size, Sector and CSR activities are more related to describing organization structure and businesses and whether some of theirs activities are sustainable. Even more, CSR activities is an indicator laying emphasis on the actions and practices conducted by organizations to achieve theirs sustainability responsibilities. These CSR-related activities are related to specific CSR component - social, environmental and governance.

Some convergence between our findings and the literature is found. Indeed, CSR disclosure content underlines information related to approach used to conduct sustainable activities. This CSR approach is highlighted throughout disclosing information related to CSR stakeholders; CSR components and CSR management system. Information related to CSR stakeholders emphasize to what extent organization businesses are continuously managed to meet the stakeholders' expectations. In this sense, CSR disclosure reveals whether CSR approach implies that managers behave with integrity regarding the larger society (Cheng et al., 2014; Frias-Aceituno, Rodriguez-Ariza, \& Garcia-Sanchez, 2013; García-Marzá, 2005; Key \& Popkin, 1998). Regarding CSR components, CSR reports disclose the target of organization sustainable activities and actions. Organization management adopts particular approach for making its supply chain management processes more transparent and thus sustainable. So, this sustainability is measured by its impact regarding three corporate responsibilities social, environmental and governance (Branco \& Rodrigues, 2008; Haji, 2013; Hamid, 2004; Jizi et al., 2013; 
Reverte, 2009). In this context, it is reported whether CSR approach is designed to be managed and optimized throughout achieving all three sustainability responsibilities - value creation - or just limited to specific sustainability area. The CSR management system is also an important aspect that reveals the CSR approach nature. In fact, CSR disclosure underlines, by information related to CSR management system, tools; processes; scope and geography of CSR activities and actions conducted by organization (Font, Walmsley, Cogotti, McCombes, \& Häusler, 2012; Jamali, 2008; Khan et al., 2013; Muttakin et al., 2015; Saleh et al., 2010; Uddin et al., 2018). Subsequently, these information would be useful and insightful for stakeholders (internal and external) to assess whether CSR approach encompasses a set of processes formalized and institutionalized in the organizational setting. This formalization is based on specific standards (Castka \& Balzarova, 2008; Chae, 2015; Zeng, Tam, Tam, \& Deng, 2005) with the purpose of integrating CSR-related activities into business strategy (Jesús Barrena Martínez et al., 2016; Mežinska et al., 2015). This integration would be achievable by means of an organization-wide infrastructure for enhancing organizational sustainability capabilities (Asif et al., 2013; Ciliberti et al., 2008). Besides, information related to CSR approach is always mutually disclosed and analyzed with information related to CSR determinants. This kind of information shed light on the motivations and stimulus for integrating CSR processes into business strategy. This integration would be motivated by several stimulus - isomorphisms. These isomorphisms highlight the fact that supply chain management is sustainable by confidence or conviction or just to meet legal and political pressures. In essence, CSR reports disclose organizational behaviour regarding CSR activities based on specific approach. Accordingly, information related to CSR approach are large-scale revealed and deeply analyzed by disclosing the level of organizational integrity regarding the larger society (Giannarakis, 2014; Holder-Webb et al., 2009, p.; Jennings \& Zandbergen, 1995; Kansal et al., 2014; Roberts, 1992).

In this perspective, CSR disclosure content nature is based on revealing the CSR approach - value creation, management tool or philanthropy. So, all the information related to CSR activities and actions are disclosed and analyzed to deal with stakeholders' expectations under specific approach. However, specific CSR information are more able to predict CSR approach nature than the others. These information are related to CSR determinants and CSR management system. About the information related to CSR management system, CSR disclosure shed light on the CSR approach by revealing whether CSR processes are standardized and formalized at corporate level. As well, CSR approach nature is predictable by explaining which tool is used to make organization business more sustainable. As a complement, CSR determinants information are predicable towards CSR approach by communicating reasons behind making supply chain management green and thus shaping managers behaviour to be more based on balancing between financial/economic performance and social performance.

Finally, it could be argued that the CSR disclosure content is more oriented to reveal information about stakeholders' expectations and how organization management use tools and processes to meet these expectations. As well, CSR disclosure reveals a set of information for specific purpose that is highlighting CSR approach nature. In this sense, specific information found in CSR reports could predict the nature of this approach. These information or indicators emphasize to what extent CSR approach is designed to achieve all the three sustainability responsibilities.

\section{Conclusion}

This article had as intention to improve our knowledge about the nature of the CSR disclosure content and the ability of specific CSR-related information for predicting the nature of the CSR approach. For this purpose, we try to emphasize whether the CSR approach is based on making supply chain management sustainable and thus achieving stakeholders' expectations when we look at these information. Therefore, we use heterogeneous CSR-related information published by Moroccan organizations in order to explore their corporate websites content.

This research has some limitations by which further research questions could be opened. These limits can be summarized in three points. First, results obtained from this survey are related to Moroccan context. Therefore, future researches could be conducted in other similar contexts in order to deepen our findings. Second, in this research we use six indicators but others indicators are also available, and thus could be added to investigate the strength of their predictability regarding the CSR approach nature. Third, we used data extracted from annual reports and statement to explore the CSR disclosure content. However, further researches can investigate about CSR-related information not communicated by Moroccan organizations throughout interacting directly with these organizations managers.

\section{References}

Alsop, R. J. (2004). Corporate reputation: Anything but superficial - the deep but fragile nature of corporate 
reputation. Journal of Business Strategy, 25(6), 21-29. https://doi.org/10.1108/02756660410699900

Asif, M., Searcy, C., Zutshi, A., \& Fisscher, O. A. M. (2013). An integrated management systems approach to corporate social responsibility. Journal of Cleaner Production, 56, 7-17. https://doi.org/10.1016/j.jclepro.2011.10.034

Azapagic, A. (2003). Systems Approach to Corporate Sustainability: A General Management Framework. Process Safety and Environmental Protection: Transactions of the Institution of Chemical Engineers, Part B, 81(5), 303-316. https://doi.org/10.1205/095758203770224342

Banerjee, S. B. (2008). Corporate social responsibility: The good, the bad and the ugly. Critical Sociology, 34(1), 51-79. https://doi.org/10.1177/0896920507084623

Barnett, M. L., \& Salomon, R. M. (2006). Beyond dichotomy: The curvilinear relationship between social responsibility and financial performance. Strategic Management Journal, 27(11), 1101-1122. https://doi.org/10.1002/smj.557

Barrena Martínez, J., López Fernández, M., \& Romero Fernández, P. M. (2016). Corporate social responsibility: Evolution through institutional and stakeholder perspectives. European Journal of Management and Business Economics, 25(1), 8-14. https://doi.org/10.1016/j.redee.2015.11.002

Barrena Martínez, J., López Fernández, M., \& Romero Fernández, P. M. (2016). Corporate social responsibility: Evolution through institutional and stakeholder perspectives. European Journal of Management and Business Economics, 25(1), 8-14. https://doi.org/10.1016/j.redee.2015.11.002

Basu, K., \& Palazzo, G. (2008). Corporate social responsibility: A process model of sensemaking. Academy of Management Review, 33(1), 122-136. https://doi.org/10.5465/AMR.2008.277455504

Branco, M. C., \& Rodrigues, L. L. (2008). Factors influencing social responsibility disclosure by Portuguese companies. Journal of Business Ethics, 83(4), 685-701. https://doi.org/10.1007/s10551-007-9658-z

Carroll, A. B. (1991). The pyramid of corporate social responsibility: Toward the moral management of $\begin{array}{llll}\text { organizational stakeholders. } & \text { Business } & \text { Horizons, } & 34(4),\end{array}$ https://doi.org/10.1016/0007-6813(91)90005-G

Castka, P., \& Balzarova, M. A. (2008). The impact of ISO 9000 and ISO 14000 on standardisation of social responsibility-an inside perspective. International Journal of Production Economics, 113(1), 74-87. https://doi.org/10.1016/j.ijpe.2007.02.048

Chae, B. (2015). Insights from hashtag supplychain and Twitter analytics: Considering Twitter and Twitter data for supply chain practice and research. International Journal of Production Economics, 165, 247-259. https://doi.org/10.1016/j.ijpe.2014.12.037

Cheng, B., Ioannou, I., \& Serafeim, G. (2014). Corporate social responsibility and access to finance. Strategic Management Journal, 35(1), 1-23. https://doi.org/10.1002/smj.2131

Ciliberti, F., Pontrandolfo, P., \& Scozzi, B. (2008). Investigating corporate social responsibility in supply chains: A SME perspective. Journal of Cleaner Production, 16(15), 1579-1588. https://doi.org/10.1016/j.jclepro.2008.04.016

Cohen, J., Holder-Webb, L., Nath, L., \& Wood, D. (2011). Retail investors' perceptions of the decision-usefulness of economic performance, governance, and corporate social responsibility disclosures. Behavioral Research in Accounting, 23(1), 109-129. https://doi.org/10.2308/bria.2011.23.1.109

Cruz, J. M. (2009). The impact of corporate social responsibility in supply chain management: Multicriteria decision-making approach. Decision Support Systems, 48(1), 224-236. https://doi.org/10.1016/j.dss.2009.07.013

Cuadrado-Ballesteros, B., Rodríguez-Ariza, L., \& García-Sánchez, I.-M. (2015). The role of independent directors at family firms in relation to corporate social responsibility disclosures. International Business Review, 24(5), 890-901. https://doi.org/10.1016/j.ibusrev.2015.04.002

Dao, V., Langella, I., \& Carbo, J. (2011). From green to sustainability: Information Technology and an integrated sustainability framework. Journal of Strategic Information Systems, 20(1), 63-79. https://doi.org/10.1016/j.jsis.2011.01.002

De Tienne, K. B., \& Lewis, L. W. (2005). The pragmatic and ethical barriers to corporate social responsibility disclosure: The Nike case. J. of Business Ethics, 60(4), 359-376. https://doi.org/10.1007/s10551-005-0869-x 
Dhaliwal, D., Li, O. Z., Tsang, A., \& Yang, Y. G. (2014). Corporate social responsibility disclosure and the cost of equity capital: The roles of stakeholder orientation and financial transparency. Journal of Accounting and Public Policy, 33(4), 328-355. https://doi.org/10.1016/j.jaccpubpol.2014.04.006

Dhaliwal, D. S., Radhakrishnan, S., Tsang, A., \& Yang, Y. G. (2012). Nonfinancial disclosure and analyst forecast accuracy: International evidence on corporate social responsibility disclosure. Accounting Review, 87(3), 723-759. https://doi.org/10.2308/accr-10218

Dias, A., Rodrigues, L. L., \& Craig, R. (2016). Global financial crisis and corporate social responsibility disclosure. Social Responsibility Journal, 12(4), 654-671. https://doi.org/10.1108/SRJ-01-2016-0004

Evangelinos, K., Skouloudis, A., Jones, N., Isaac, D., \& Sfakianaki, E. (2016). Exploring the status of corporate social responsibility disclosure in the UK building and construction industry. International Journal of Global Environmental Issues, 15(4), 377-399. https://doi.org/10.1504/IJGENVI.2016.081068

Farook, S., Kabir Hassan, M., \& Lanis, R. (2011). Determinants of corporate social responsibility disclosure: The case of Islamic banks. Journal of Islamic Accounting and Business Research, 2(2), 114-141. https://doi.org/10.1108/17590811111170539

Font, X., Walmsley, A., Cogotti, S., McCombes, L., \& Häusler, N. (2012). Corporate social responsibility: The disclosure-performance gap. Tourism Management, $33(6), \quad$ 1544-1553. https://doi.org/10.1016/j.tourman.2012.02.012

Frias-Aceituno, J. V., Rodriguez-Ariza, L., \& Garcia-Sanchez, I. M. (2013). The role of the board in the dissemination of integrated corporate social reporting. Corporate Social Responsibility and Environmental Management, 20(4), 219-233. https://doi.org/10.1002/csr.1294

García-Marzá, D. (2005). Trust and dialogue: Theoretical approaches to ethics auditing. Journal of Business Ethics, 57(3), 209-219. https://doi.org/10.1007/s10551-004-8202-7

Giannarakis, G. (2014). Corporate governance and financial characteristic effects on the extent of corporate social responsibility disclosure. Social Responsibility Journal, 10(4), 569-590. https://doi.org/10.1108/SRJ-02-2013-0008

Haji, A. A. (2013). Corporate social responsibility disclosures over time: Evidence from Malaysia. Managerial Auditing Journal, 28(7), 647-676. https://doi.org/10.1108/MAJ-07-2012-0729

Hamid, F. Z. A. (2004). Corporate social disclosure by banks and finance companies: Malaysian evidence. Corporate Ownership and Control, 1(4), 118-130. https://doi.org/10.22495/cocv1i4p10

Herrera Madueño, J., Larrán Jorge, M., Martínez Conesa, I., \& Martínez-Martínez, D. (2016). Relationship between corporate social responsibility and competitive performance in Spanish SMEs: Empirical evidence from a stakeholders' perspective. BRQ Business Research Quarterly, 19(1), 55-72. https://doi.org/10.1016/j.brq.2015.06.002

Holder-Webb, L., Cohen, J. R., Nath, L., \& Wood, D. (2009). The supply of corporate social responsibility disclosures among U.S. firms. Journal of Business Ethics, 84(4), 497-527. https://doi.org/10.1007/s10551-008-9721-4

Hutchins, M. J., \& Sutherland, J. W. (2008). An exploration of measures of social sustainability and their application to supply chain decisions. Journal of Cleaner Production, 16(15), 1688-1698. https://doi.org/10.1016/j.jclepro.2008.06.001

Jamali, D. (2008). A stakeholder approach to corporate social responsibility: A fresh perspective into theory and practice. Journal of Business Ethics, 82(1), 213-231. https://doi.org/10.1007/s10551-007-9572-4

Jennings, P. D., \& Zandbergen, P. A. (1995). Ecologically Sustainable Organizations: An Institutional Approach. The Academy of Management Review, 20(4), 1015-1052. https://doi.org/10.2307/258964

Jizi, M. I., Salama, A., Dixon, R., \& Stratling, R. (2013). Corporate Governance and Corporate Social Responsibility Disclosure: Evidence from the US Banking Sector. Journal of Business Ethics, 125(4), 601-615. https://doi.org/10.1007/s10551-013-1929-2

Johnson, M. P. (2015). Sustainability Management and Small and Medium-Sized Enterprises: Managers' Awareness and Implementation of Innovative Tools. Corporate Social Responsibility and Environmental Management, 22(5), 271-285. https://doi.org/10.1002/csr.1343

Kansal, M., Joshi, M., \& Batra, G. S. (2014). Determinants of corporate social responsibility disclosures: 
Evidence from India. Advances in Accounting, 30(1), 217-229. https://doi.org/10.1016/j.adiac.2014.03.009

Key, S., \& Popkin, S. J. (1998). Integrating ethics into the strategic management process: Doing well by doing good. Management Decision, 36(5), 331-338. https://doi.org/10.1108/00251749810220531

Khan, A., Muttakin, M. B., \& Siddiqui, J. (2013). Corporate Governance and Corporate Social Responsibility Disclosures: Evidence from an Emerging Economy. Journal of Business Ethics, 114(2), 207-223. https://doi.org/10.1007/s10551-012-1336-0

Kolk, A., \& Pinkse, J. (2010). The integration of corporate governance in corporate social responsibility disclosures. Corporate Social Responsibility and Environmental Management, 17(1), 15-26. https://doi.org/10.1002/csr.196

Leon-Soriano, R., Muñoz-Torres, M. J., \& Chalmeta-Rosaleñ, R. (2010). Methodology for sustainability strategic planning and management. Industrial Management and Data Systems, 110(2), 249-268. https://doi.org/10.1108/02635571011020331

Lozano, R. (2012). Towards better embedding sustainability into companies' systems: An analysis of voluntary corporate initiatives. J. of Cleaner Production, 25, 14-26. https://doi.org/10.1016/j.jclepro.2011.11.060

Maas, S., \& Reniers, G. (2014). Development of a CSR model for practice: Connecting five inherent areas of sustainable business. J. of Cleaner Production, 64, 104-114. https://doi.org/10.1016/j.jclepro.2013.07.039

Mežinska, I., Lapiņa, I., \& Mazais, J. (2015). Integrated management systems towards sustainable and socially responsible organisation. Total Quality Management and Business Excellence, 26(5-6), 469-481. https://doi.org/10.1080/14783363.2013.835899

Muttakin, M. B., Khan, A., \& Azim, M. I. (2015). Corporate social responsibility disclosures and earnings quality: Are they a reflection of managers' opportunistic behavior? Managerial Auditing Journal, 30(3), 277-298. https://doi.org/10.1108/MAJ-02-2014-0997

Ntim, C. G., \& Soobaroyen, T. (2013). Black Economic Empowerment Disclosures by South African Listed Corporations: The Influence of Ownership and Board Characteristics. Journal of Business Ethics, 116(1), 121-138. https://doi.org/10.1007/s10551-012-1446-8

Ortas, E., Moneva, J. M., \& Álvarez, I. (2014). Sustainable supply chain and company performance: A global examination. Supply Chain Management, 19(3), 332-350. https://doi.org/10.1108/SCM-12-2013-0444

Petrini, M., \& Pozzebon, M. (2009). Managing sustainability with the support of business intelligence: Integrating socio-environmental indicators and organisational context. Journal of Strategic Information Systems, 18(4), 178-191. https://doi.org/10.1016/j.jsis.2009.06.001

Pyo, G., \& Lee, H.-Y. (2013). The association between corporate social responsibility activities and earnings quality: Evidence from donations and voluntary issuance of CSR reports. Journal of Applied Business Research, 29(3), 945-962. Consulté à l'adresse Scopus.

Reverte, C. (2009). Determinants of corporate social responsibility disclosure ratings by Spanish listed firms. Journal of Business Ethics, 88(2), 351-366. https://doi.org/10.1007/s10551-008-9968-9

Roberts, R. W. (1992). Determinants of corporate social responsibility disclosure: An application of stakeholder theory. Accounting, Organizations and Society, 17(6), 595-612. https://doi.org/10.1016/0361-3682(92)90015-K

Robertson, D. C., \& Nicholson, N. (1996). Expressions of corporate social responsibility in U.K. Firms. Journal of Business Ethics, 15(10), 1095-1106. https://doi.org/10.1007/BF00412050

Saleh, M., Zulkifli, N., \& Muhamad, R. (2010). Corporate social responsibility disclosure and its relation on institutional ownership: Evidence from public listed companies in Malaysia. Managerial Auditing Journal, 25(6), 591-613. https://doi.org/10.1108/02686901011054881

Schwartz, B., \& Tilling, K. (2009). "ISO-lating" corporate social responsibility in the organizational context: A dissenting interpretation of ISO 26000. Corporate Social Responsibility and Environmental Management, 16(5), 289-299. https://doi.org/10.1002/csr.211

Sen, S., Bhattacharya, C. B., \& Korschun, D. (2006). The role of corporate social responsibility in strengthening multiple stakeholder relationships: A field experiment. Journal of the Academy of Marketing Science, 34(2), 158-166. https://doi.org/10.1177/0092070305284978

Surroca, J., Tribó, J. A., \& Waddock, S. (2010). Corporate responsibility and financial performance: The role of 
intangible resources. Strategic Management Journal, 31(5), 463-490. https://doi.org/10.1002/smj.820

Uddin, S., Siddiqui, J., \& Islam, M. A. (2018). Corporate Social Responsibility Disclosures, Traditionalism and Politics: A Story from a Traditional Setting. Journal of Business Ethics, 151(2), 409-428. https://doi.org/10.1007/s10551-016-3214-7

Wang, J., Song, L., \& Yao, S. (2013). The determinants of corporate social responsibility disclosure: Evidence from China. Journal of Applied Business Research, 29(6), 1833-1847. Consulté à l'adresse Scopus.

Wuttichindanon, S. (2017). Corporate social responsibility disclosure - choices of report and its determinants: Empirical evidence from firms listed on the Stock Exchange of Thailand. Kasetsart Journal of Social Sciences, 38(2), 156-162. https://doi.org/10.1016/j.kjss.2016.07.002

Zeng, S. X., Tam, C. M., Tam, V. W. Y., \& Deng, Z. M. (2005). Towards implementation of ISO 14001 environmental management systems in selected industries in China. Journal of Cleaner Production, 13(7), 645-656. https://doi.org/10.1016/j.jclepro.2003.12.009

\section{Appendixes}

\section{Appendix A. CSR Codes Matrix}

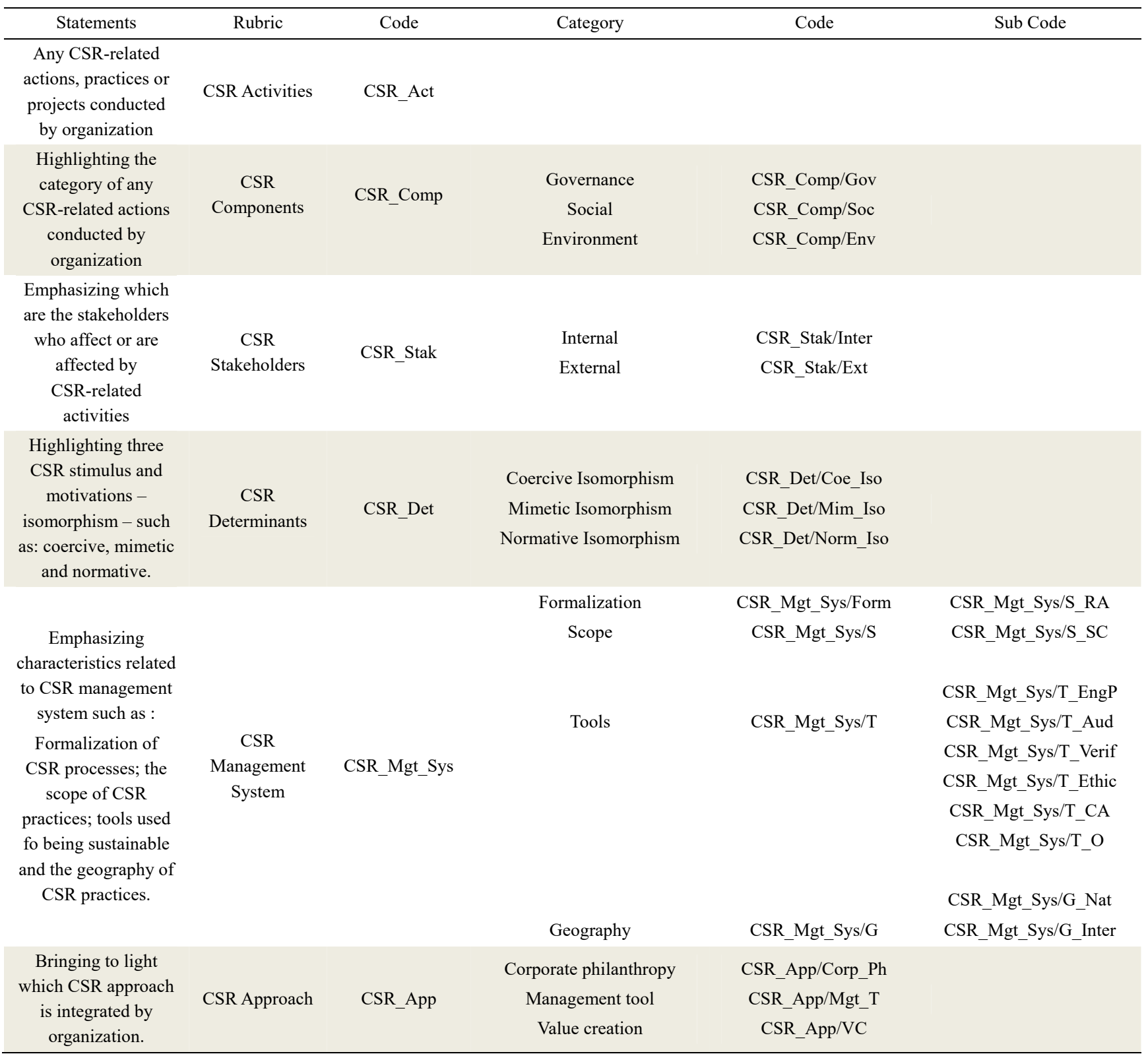




\section{Appendix B. Codes frequencies matrix across documents - nodes presentation}

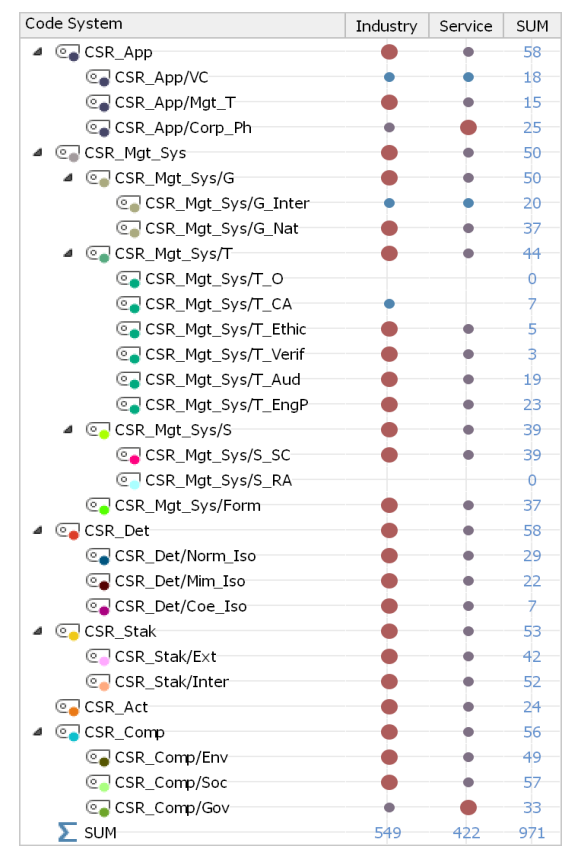

\section{Appendix C. Codes overlapping frequencies matrix - arithmetic presentation}

\begin{tabular}{|c|c|c|c|c|c|c|c|c|c|}
\hline Code System & CSR_App & CSR_App/NC & CSR_App/Mgt_T & CSR_App/Corp_Ph & CSR_Det & CSR_Det/Norm_Iso & CSR_Det/Mim_Iso & CSR_Det/Coe_Iso & SUM \\
\hline$\triangle$ CSR_App & & 18 & 15 & 25 & 36 & 18 & 15 & 3 & 130 \\
\hline$\sigma_{\bullet}$ CSR_App/NC & 18 & & & & 9 & 9 & & & 36 \\
\hline$\sigma_{\bullet}$ CSR_App/Mgt_T & 15 & & & & 10 & 7 & 2 & 1 & 35 \\
\hline @CSR_App/Corp_Ph & 25 & & & & 16 & 1 & 13 & 2 & 57 \\
\hline$\Delta$ aCSR_Mgt_Sys & 26 & 9 & 10 & 7 & 22 & 11 & 6 & 5 & 96 \\
\hline$\Delta{ }_{0}$ CSR_Mgt_Sys/G & 20 & 6 & 5 & 9 & 9 & 6 & 1 & 2 & 58 \\
\hline$\varrho_{0}$ CSR_Mgt_Sys/G_Inter & 5 & 4 & & 1 & 4 & 4 & & & 18 \\
\hline ae CSR_Mgt_Sys/G_Nat & 17 & 4 & 5 & 8 & 7 & 4 & 1 & 2 & 48 \\
\hline$\Delta \sigma_{-}$CSR_Mgt_Sys/T & 13 & 7 & 6 & & 9 & 6 & 1 & 2 & 44 \\
\hline$Q_{0}$ CSR_Mgt_Sys/T_O & & & & & & & & & 0 \\
\hline ⒸSR_Mgt_Sys/T_CA & 5 & 3 & 2 & & 5 & 4 & 1 & & 20 \\
\hline$\varrho_{0}$ CSR_Mgt_Sys/T_Ethic & & & & & & & & & 0 \\
\hline$\varrho_{\bullet}$ CSR_Mgt_Sys/T_Verif & & & & & & & & & 0 \\
\hline @CSR_Mgt_Sys/T_Aud & 3 & & 3 & & 3 & 1 & & 2 & 12 \\
\hline$\sigma_{e}$ CSR_Mgt_Sys/T_EngP & 7 & 4 & 3 & & 2 & 2 & & & 18 \\
\hline$\Delta \odot$ CSR_Mgt_Sys/S & 12 & 4 & 6 & 1 & 7 & 5 & 1 & 1 & 37 \\
\hline$\sigma_{\bullet}$ CSR_Mgt_Sys/S_SC & 12 & 4 & 6 & 1 & 7 & 5 & 1 & 1 & 37 \\
\hline GCSR_Mgt_Sys/S_RA & & & & & & & & & 0 \\
\hline @ed CSR_Mgt_Sys/Form & 13 & 5 & 7 & & 5 & 2 & 1 & 2 & 35 \\
\hline$\triangle$ CSR_Det & 36 & 9 & 10 & 16 & & 29 & 22 & 7 & 129 \\
\hline$\bullet_{\bullet}$ CSR_Det/Norm_Iso & 18 & 9 & 7 & 1 & 29 & & & & 64 \\
\hline$\bullet$ CSR_Det/Mim_Iso & 15 & & 2 & 13 & 22 & & & & 52 \\
\hline$\sigma$ CSR_Det/Coe_Iso & 3 & & 1 & 2 & 7 & & & & 13 \\
\hline$\Delta$ • & 19 & 7 & 4 & 8 & 12 & 5 & 6 & 1 & 62 \\
\hline (व) CSR_Stak/Ext & 13 & 6 & 4 & 3 & 6 & 4 & 2 & & 38 \\
\hline @CSR_Stak/Inter & 17 & 7 & 3 & 7 & 11 & 5 & 5 & 1 & 56 \\
\hline Q] CSR_Act & 4 & 2 & 2 & & 3 & 3 & & & 14 \\
\hline$\Delta$ CSR_Comp & 24 & 7 & 11 & 6 & 15 & 11 & 4 & & 78 \\
\hline QCSR_Comp/Env & 12 & 2 & 7 & 3 & 3 & 2 & 1 & & 30 \\
\hline c] CSR_Comp/Soc & 15 & 4 & 5 & 6 & 8 & 7 & 1 & & 46 \\
\hline$\varrho_{2}$ CSR_Comp/Gov & 7 & 1 & 6 & & 2 & 2 & & & 18 \\
\hline$\Sigma$ sum & 374 & 122 & 130 & 117 & 269 & 153 & 84 & 32 & 1281 \\
\hline
\end{tabular}

\section{Appendix D. Tests of Equality of Group Means}

\begin{tabular}{|c|c|c|c|c|c|}
\hline & Wilks' Lambda & $\mathrm{F}$ & df1 & df2 & Sig. \\
\hline CSR Management System Tools & 890 & 3,403 & 2 & 55 & ,040 \\
\hline CSR Management System Formalization & 662 & 14,018 & 2 & 55 &, 000 \\
\hline CSR Determinants & ,627 & 16,331 & 2 & 55 &, 000 \\
\hline Sector & ,975 & ,699 & 2 & 55 &, 501 \\
\hline Size & ,976 & ,686 & 2 & 55 &, 508 \\
\hline CSR Activities & ,958 & 1,192 & 2 & 55 & ,311 \\
\hline
\end{tabular}




\section{Appendix E. Graphic displaying the canonical discriminant functions}

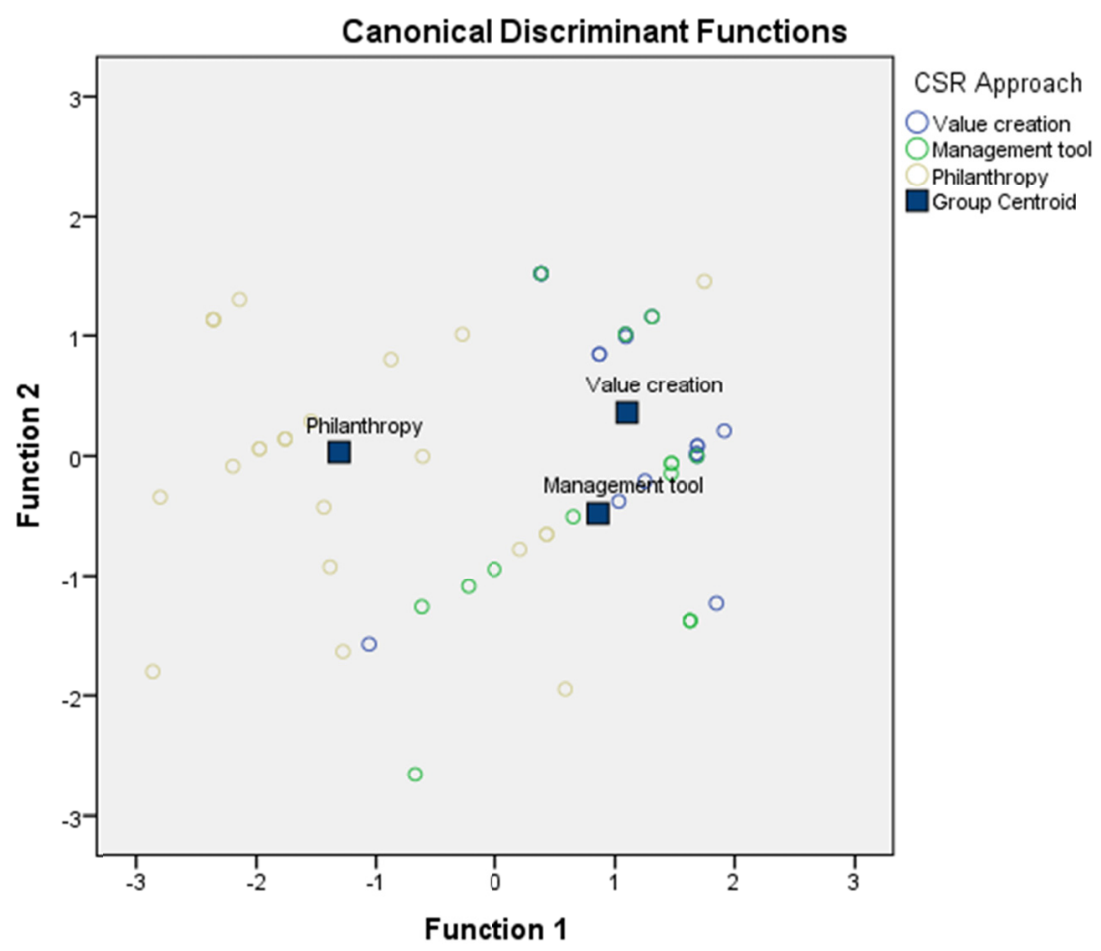

\section{Copyrights}

Copyright for this article is retained by the author(s), with first publication rights granted to the journal.

This is an open-access article distributed under the terms and conditions of the Creative Commons Attribution license (http://creativecommons.org/licenses/by/4.0/). 